\title{
EFFECT OF RADICAL SCAVENGERS AND PROPOSED PATHWAYS FOR AZO DYE DEGRADATION IN A PERSULPHATE-BISULFITE SYSTEM
}

\author{
Zhong H., Sun L., Fang J., Zhao H., Xu A., Xia D., Nevsky A. V. \\ ВЛИЯНИЕ АКЦЕПТОРОВ РАДИКАЛОВ И СХЕМА ДЕСТРУКЦИИ \\ АЗОКРАСИТЕЛЯ В СИСТЕМЕ ПЕРСУЛЬФАТ-БИСУЛЬФИТ
}

\author{
Чжун Х., Сунь Л., Фан Ц., Чжао Х., Сюй А., Ся Д., Невский А. В.
}

\begin{abstract}
Introduction. The textile industry is one of the most significant manufacturing sectors that produce large volumes of highly polluted and toxic wastewater. Along with the light industry, pigments and dyes industry, domestic service, dry-cleaning, etc., it contributes significantly to water pollution, where dyes are among the top pollutants. Methods. In this study, the degradation of Acid Orange 7 (AO7) dye in a persulfate-bisulfite system under visible (Vis) light (wavelength $\geq 420 \mathrm{~nm}$ ) was performed. Based on the electron spin resonance spin-trapping technologies and radical scavenger measurements, the produced hydroxyl radical $(\cdot \mathrm{OH})$ is regarded as the predominant reactive oxidant for AO7 decolorization also involving the sulfate radical $\left(\mathrm{SO}_{4}^{-}{ }^{-}\right)$. The formation of shortlived radicals during AO7 decolorization was detected by the ESR spin-trapping technique at room temperature using a Bruker ESR A-300 spectrometer with the following parameters: center field $3516 \mathrm{G}$, sweep width $100 \mathrm{G}$, microwave frequency $9.86 \mathrm{G}$, modulation frequency $100 \mathrm{kHz}$, microwave power $1 \mathrm{~mW}$. The intermediate products of the $\mathrm{AO} 7$ degradation reaction were analyzed by mass spectrometry. The experiments were performed using an Esquire LC ion trap mass spectrometer (Bruker Daltonics, Bremen, Germany) equipped with an orthogonal geometry ESI source. Nitrogen was used as a drying (3 L/min) and nebulizing (6 psi) gas at $300{ }^{\circ} \mathrm{C}$. The spray shield voltage was $4.0 \mathrm{kV}$ and the capillary cap voltage was $4.5 \mathrm{kV}$. Scanning was performed from m/z 90 to 400 in the standard resolution mode at a scan rate of $13 \mathrm{kDa} / \mathrm{s}$. Before the analysis, each sample was diluted ten-fold. The intermediates were determined by electrospray ionization-mass spectrometry (ESI-MS) analysis and, as a result, a plausible degradation pathway was proposed. Results. The results of the study can be useful in designing a simple, effective, and economically sound system for the treatment of non-biodegradable azo dyes.
\end{abstract}

Keywords: dye degradation, Acid Orange 7, radical scavengers, reaction intermediates, degradation pathway, mineralization.

\begin{abstract}
Аннотация
Введение. Текстильная промышленность принадлежит к одной из наиболее важных отраслей производства, которые являются источником больших объемов сильно загрязненных и токсичных сточных вод. Наряду слегкой промышленностью, производством пигментов и красителей, сферой бытового обслуживания, химчисткой и т.д., она вносит значительный вклад в загрязнение водной среды, в которой красители рассматриваются как одни из главных загрязняющих веществ. Методы. В данном исследовании изучен процесс деструкции красителя кислотного оранжевого 7 (КО7) в системе персульфатбисульфит при облучении видимым светом (длина волны $\geq 420$ нм). С помощью использованного нами метода электронного спинового резонанса и детектирования акцепторов радикалов установлено, что образующийся гидроксильный радикал $(\cdot \mathrm{OH})$ можно рассматривать в качестве основного реакционно-способного окислителя для обесцвечивания КО7 с участием в процессе сульфатного радикала (SO4--). Образование короткоживущих радикалов в процессе обесцвечивания КО7 детектировали методом ESR спинового улавливания при комнатной температуре с использованием спектрометра Bruker ESR A-300 со следующими характеристиками: центральное поле $3516 \mathrm{G}$, ширина развертки $100 \mathrm{G}$, микроволновая частота 9,86 G, частота модуляции 100 кГц, микроволновая мощность 1 мВт. Определение промежуточных продуктов процесса деструкции КО7 проводили масс-спектрометрически. В ходе эксперимента использовали масс-спектрометр с ионной ловушкой Esquire LC (Bruker Daltonics, Бремен, Германия), оснащенный источником ESI с ортогональной геометрией. Азот использовали в качестве осушающего (3 л/мин) и распыляющего (6 фунтов/кв. дюйм) газа при температуре $300{ }^{\circ} \mathrm{C}$. Напряжение защитного экрана составляло 4,0 кВ, а напряжение капиллярного колпачка было равно 4,5 кВ. Сканирование проводили при значениях отношения $\mathrm{m} / \mathrm{z}$ (масса/заряд) в интервале от 90 до 400 в режиме стандартного разрешения со скоростью сканирования $13 \mathrm{\kappa Да/с.} \mathrm{Перед} \mathrm{проведением} \mathrm{анализа} \mathrm{каждый} \mathrm{образец} \mathrm{разбавляли} \mathrm{в} \mathrm{десять} \mathrm{раз.} \mathrm{Результаты.}$ Промежуточные продукты реакции определяли с помощью метода масс-спектрометрии с ионизацией электрораспылением (ESI-MS), и в итоге предложена вероятная схема процесса деструкции. Результаты исследования могут быть полезны при разработке не сложной, эффективной и экономически обоснованной системы обработки стоков от не биоразлагаемых азокрасителей.
\end{abstract}

Ключевые слова: деструкция красителя, краситель кислотный оранжевый 7, акцепторы радикалов, промежуточные продукты реакции, путь деструкции, минерализация. 


\section{Introduction}

Earlier, the authors of the paper performed degradation of Acid Orange 7 (AO7) dye in a persulfate-bisulfite system under visible (Vis) light (wavelength $\geq 420 \mathrm{~nm}$ ). Activities of different systems including $\mathrm{HSO}_{3}^{-} / \mathrm{Vis}, \mathrm{HSO}_{3}^{-} / \mathrm{PS}, \mathrm{PS} / \mathrm{Vis}$ and $\mathrm{HSO}_{3}^{-} / \mathrm{PS} / \mathrm{Vis}$ were evaluated. It was found that the efficiency of PS/Vis system was negligible, and almost 29 and $40 \%$ of AO7 were oxidized by $\mathrm{HSO}_{3}^{-} / \mathrm{Vis}$ and $\mathrm{HSO}_{3}^{-} / \mathrm{PS}$, respectively, within $30 \mathrm{~min}$; that was further improved to almost $94 \%$ within $30 \mathrm{~min}$ in the $\mathrm{HSO}_{3}^{-} / \mathrm{PS} / \mathrm{Vis}$ system at room temperature. Various operational parameters, such as PS concentration, $\mathrm{HSO}_{3}^{-}$concentration and initial $\mathrm{pH}$, were investigated to optimize the process.

In previous reports, free radicals, such as the generated hydroxyl radical $(\cdot \mathrm{OH})$ and sulfate radical $\left(\mathrm{SO}_{4}{ }^{-}\right)$, were thought to be produced during the reaction between $\mathrm{HSO}_{3}{ }^{-}$and $\mathrm{PS}[5,12,14]$. In this study, primary reactive oxidants and final degradation products of $\mathrm{AO} 7$ in the $\mathrm{HSO}_{3}^{-} / \mathrm{PS} / \mathrm{Vis}$ process were investigated to propose $\mathrm{AO} 7$ degradation pathways.

\section{Methods and materials}

Acid Orange 7 (AO7, $\mathrm{C}_{16} \mathrm{H}_{11} \mathrm{~N}_{2} \mathrm{NaO}_{4} \mathrm{~S}$ ) dye was purchased from Aladdin Industrial Corporation. Sodium hydrogen sulfite $\left(\mathrm{NaHSO}_{3}\right)$, sodium persulfate $\left(\mathrm{Na}_{2} \mathrm{~S}_{2} \mathrm{O}_{8}\right)$, tert-Butyl alcohol (TBA, AR), ethanol (EtOH, AR) and other chemicals were analytically pure, if not noted otherwise, and were obtained from Sinopharm Chemical Reagent Co., Ltd. Acetonitrile was supplied by Sinopharm Chemical Reagent Co., Ltd. (Shanghai, China) but it was of the HPLC grade. Spin trap reagent 5,5-dimethyl-1-pyrroline-N-oxide (DMPO) was purchased from Sigma Chemical Co. All chemicals were used as received without further purification. Sample solutions were prepared using deionized water (Aquapro, USA) throughout the experiments.

\section{Degradation procedures}

All batch experiments were conducted in a $100 \mathrm{~mL}$ undivided glass beaker containing $50 \mathrm{~mL}$ solution at about $25{ }^{\circ} \mathrm{C}$ with or without exposure to Vis light irradiation (CHF-XM-500W, Beijing Trusttech Co., China). After the desired amounts of AO7 and PS in the $50 \mathrm{~mL}$ aqueous solution were added into the reactor, the reaction was initialized by adding $\mathrm{HSO}_{3}^{-}$. Each reaction solution was constantly agitated by a magnetic stirrer (model 78-1, Hangzhou Instrument Motors Factory, China).
A stock solution of $\mathrm{AO} 7$ with the initial concentration $\left(\mathrm{C}_{0}\right)$ of $20 \mathrm{mg} / \mathrm{L}$ was prepared freshly with deionized water before each run. Since PS is an acidic oxidant, the addition of PS led to a significant decrease of $\mathrm{pH}$, and the experiment was conducted

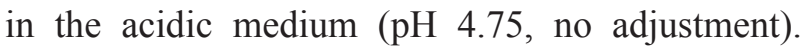
Before the beginning of the reaction, the PS solution and $\mathrm{HSO}_{3}^{-}$solution were added to the reactor.

\section{Analysis}

The AO7 degradation process was monitored by a METASH UV-5500PC spectrophotometer at the maximum absorption wavelength $(484 \mathrm{~nm})$. Solution samples were taken at predetermined time intervals and measured immediately to record temporal UV-vis spectral variations of the dye. The related reaction progress was monitored using the UV-vis absorption spectra of $\mathrm{AO} 7 \mathrm{in}$ terms of the percentage of the degraded azo dye, which was calculated based on the following equation (1):

Decolorization efficiency $(\%)=\left(\mathrm{C}_{0}-\mathrm{C}_{\mathrm{t}}\right) / \mathrm{C}_{0} \times 100$

where $\mathrm{C}_{\mathrm{t}}$ is the absorbance at $484 \mathrm{~nm}$ for $\mathrm{AO} 7$ at a given reaction time $t$, and $\mathrm{C}_{0}$ is the related initial absorbance.

The formation of short-lived radicals during AO7 decolorization was detected by the ESR spintrapping technique at room temperature using a Bruker ESR A-300 spectrometer with the following parameters: center field $3516 \mathrm{G}$, sweep width $100 \mathrm{G}$, microwave frequency $9.86 \mathrm{G}$, modulation frequency $100 \mathrm{kHz}$, microwave power $1 \mathrm{~mW}$.

The intermediate products of the $\mathrm{AO} 7$ degradation reaction were analyzed by mass spectrometry. The experiments were performed on an Esquire LC-ion trap mass spectrometer (Bruker Daltonics, Bremen, Germany) equipped with an orthogonal geometry ESI source. Nitrogen was used as a drying $(3 \mathrm{~L} / \mathrm{min})$ and nebulizing ( 6 psi) gas at $300{ }^{\circ} \mathrm{C}$. The spray shield voltage was $4.0 \mathrm{kV}$ and the capillary cap voltage was $4.5 \mathrm{kV}$. Scanning was performed from $\mathrm{m} / \mathrm{z} 90$ to 400 in the standard resolution mode at a scan rate of $13 \mathrm{kDa} / \mathrm{s}$. Before the analysis, each sample was diluted ten-fold.

\section{Results and discussion \\ Radical detection}

To understand the reaction mechanism of the persulfatebisulfite system, the formation of shortlived radicals during $\mathrm{AO} 7$ decolorization was detected by the ESR spin-trapping technique. ESR 


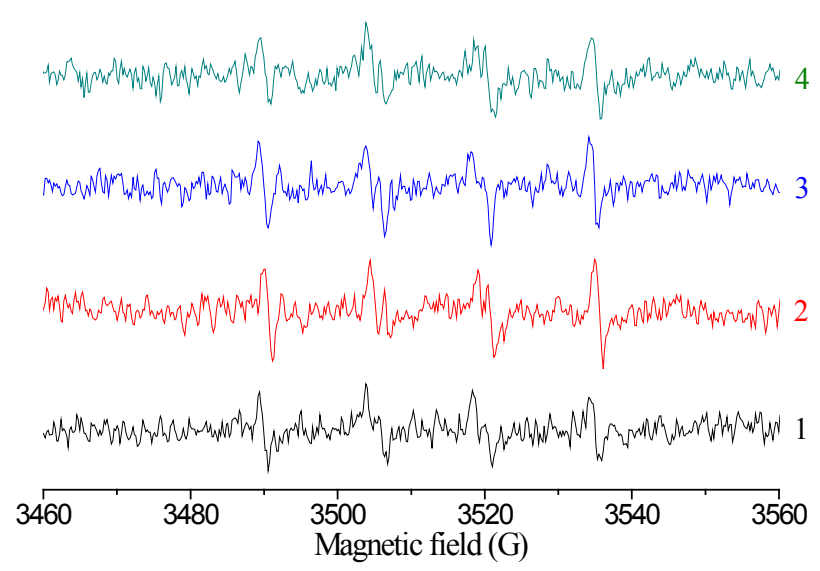

Fig. 1. DMPO spin-trapping ESR spectra at different time intervals (min): (1) 0, (2) 5, (3) 10, (4) 20.

spectra measured during the reaction are shown in Figure 1. An ESR spectrum of a sulfur trioxide anion radical adduct with the hyperfine coupling constants $\mathrm{N}=14.7 \mathrm{G}$ and $\mathrm{H} \beta=16.0 \mathrm{G}$ was observed in the experiments with persulfate, bisulfite, and DMPO under Vis light, similar to the reported rectoritesulfite system [13]. The intensity of $\mathrm{SO}_{3}{ }^{--}$adduct first increases rapidly $(5 \mathrm{~min})$ and then slowly decreases within $20 \mathrm{~min}$, implying the $\mathrm{SO}_{3} \cdot{ }^{-}$adduct transformation into other species.

\section{Effect of radical scavengers}

To evaluate the contribution of the oxidizing species $\mathrm{SO}_{4}{ }^{-}$and $\cdot \mathrm{OH}$, two kinds of radical scavengers were used: ethanol $(\mathrm{EtOH})$ and tertbutyl alcohol (TBA). As indicated in Figure 2, the addition of $1 \mathrm{M}$ EtOH almost suppressed the oxidation process. EtOH contains $\alpha$-hydrogen,

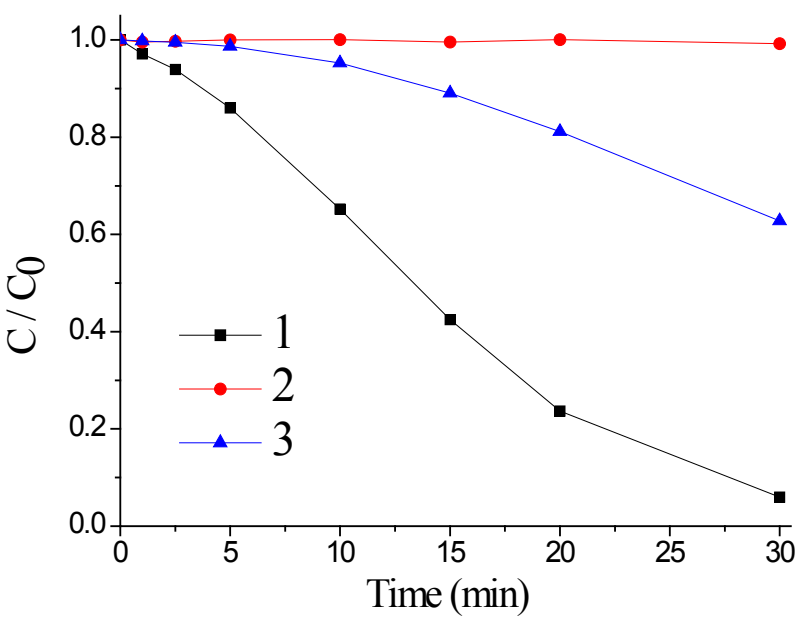

Fig. 2. Effect of radical scavengers: (1) none, (2) EtOH, (3) TBA which can rapidly quench both $\mathrm{SO}_{4} \cdot{ }^{-}$and $\cdot \mathrm{OH}$. The reaction constants for $\mathrm{EtOH}$ with $\mathrm{SO}_{4}{ }^{-}$and $\cdot \mathrm{OH}$ are $1.6-7.7 \times 10^{7} \mathrm{M}^{-1} \mathrm{~s}^{-1}$ and $1.2-2.8 \times 10^{9} \mathrm{M}^{-1} \mathrm{~s}^{-1}$, respectively [6]. Thus, the presence of EtOH led to the consumption of reactive radicals and removal efficiency decrease.

According to literature data, $\cdot \mathrm{OH}$ can be generated via the reaction between $\mathrm{SO}_{4}{ }^{-}$and water as follows [9]:

$$
\mathrm{SO}_{4}^{-{ }^{-}+} \mathrm{H}_{2} \mathrm{O} \rightarrow \mathrm{HSO}_{4}^{-}+\cdot \mathrm{OH}
$$

To investigate the contribution of $\cdot \mathrm{OH}$ to the AO7 removal in the $\mathrm{HSO}_{3}^{-} / \mathrm{PS} / \mathrm{Vis}$ process, TBA was introduced. TBA can quickly quench $\cdot \mathrm{OH}$ with the reaction constant $3.8-7.6 \times 10^{8} \mathrm{M}^{-1} \mathrm{~s}^{-1}$, which is much more than the rate constant of TBA with $\mathrm{SO}_{4} \cdot-$ (4.0-9.1 $\left.\times 10^{5} \mathrm{M}^{-1} \mathrm{~s}^{-1}\right)$. Hence, TBA is generally used as an $\cdot \mathrm{OH}$ scavenger [5]. Figure 2 shows that the addition of $1 \mathrm{M}$ TBA inhibited the oxidation process significantly and the $\mathrm{AO} 7$ removal efficiency decreased from 94 to $37 \%$ within $30 \mathrm{~min}$.

Compared with the control experiment, the addition of $1 \mathrm{M}$ TBA resulted in $57 \%$ AO7 decay drop, while the addition of $1 \mathrm{M}$ EtOH almost inhibited the degradation process. These results provide evidence that $\mathrm{OH}$ radicals are the major radical species in the persulfate-bisulfite system in the acidic medium; $\mathrm{SO}_{4} \cdot{ }^{--}$radicals are also involved but their contribution is minor compared with that of -OH radicals.

\section{Photodegradation products and proposed process pathways}

To analyze the process of $\mathrm{AO} 7$ degradation in a persulfate-bisulfite system under Vis light, we attempted to identify main reaction intermediates. Direct-infusion electrospray ionization mass spectrometry (ESI-MS), which has been the technology of the choice for detection and identification of reactants, products, and intermediates in a solution [7], was applied to identify intermediate products during $\mathrm{AO} 7$ degradation in the $\mathrm{HSO}_{3}^{-} / \mathrm{PS} /$ Vis system.

Figure 3 shows representative spectra in the negative ion mode at time intervals from 0 to $60 \mathrm{~min}$. The molecular weight of AO7 was 350 . Its corresponding structure is shown in Figure 5. In an aqueous solution, $\mathrm{RSO}_{3} \mathrm{Na}$ groups in the dye dissociate into $\mathrm{RSO}_{3}^{-}$and $\mathrm{Na}^{+}$ions. At the beginning of the reaction, an intense ion of $\mathrm{m} / \mathrm{z} 327$ 


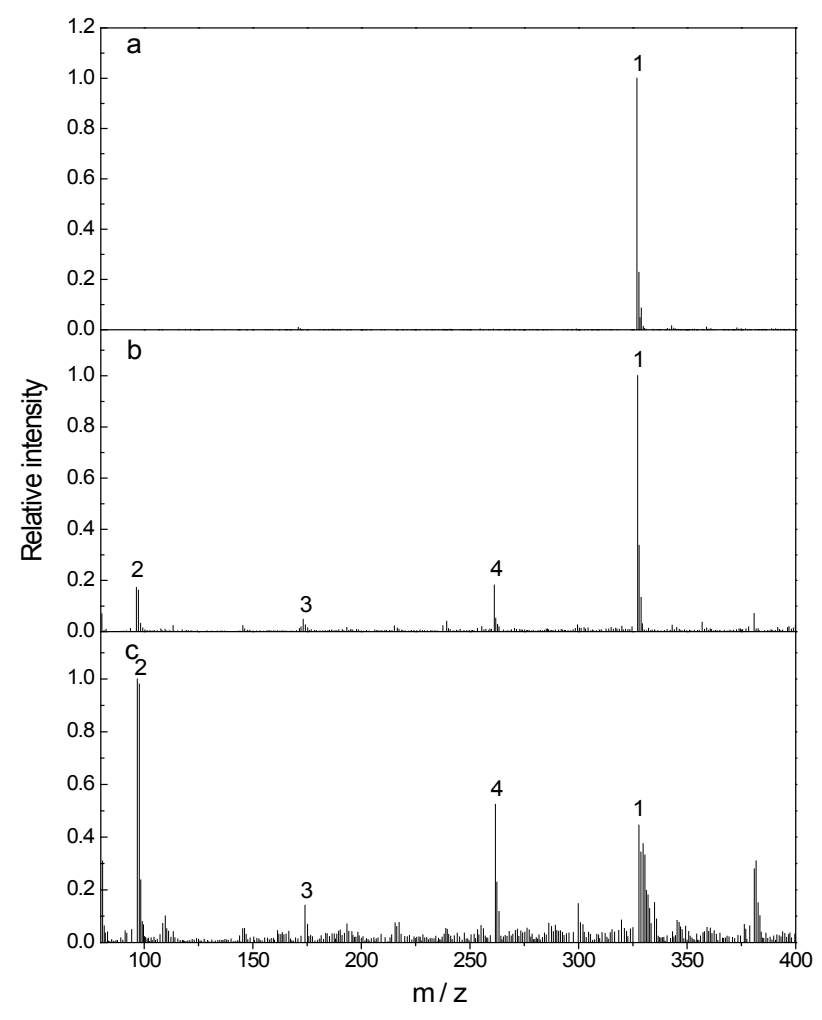

Fig. 3. ESI (-) mass spectra of AO7 solution during degradation in the $\mathrm{Vis} / \mathrm{HSO}_{3}{ }^{-} / \mathrm{PS}$ system at different time intervals ( $\left.\mathrm{min}\right)$ : (a) 0, (b) 30, (c) 60. Peak values: (1) 327, (2) 97, (3) 173, (4) 261

corresponding to $\mathrm{AO} 7[\mathrm{M}-\mathrm{Na}]^{-}$was observed as expected. After $60 \mathrm{~min}$ treatment, the intensity of AO7 at m/z 327 decreased significantly and signal peaks at $\mathrm{m} / \mathrm{z}$ 97, 173 and 261 occurred, indicating that AO7 was degraded into some intermediate products. According to the values of $\mathrm{m} / \mathrm{z}$ (173) and the suggested structures, this product can be regarded as p-phenolsulfonic acid (p-PSA), which is a common product of AO7 destruction, as was reported previously $[1-4,8,11,15-19]$. The intermediate product can then be continually oxidized to ions of $\mathrm{m} / \mathrm{z} 97$ and 261, which may be a result of ring-opening reactions. With the reaction proceeding, AO7 was further degraded to the mentioned products as the relative intensity of these ions increased after $60 \mathrm{~min}$.

The positive ionization mode was also tested to detect positively charged species. The corresponding results are shown in Figure 4. At the beginning of the reaction, an intense ion of $\mathrm{m} / \mathrm{z} 373$ corresponded to $\mathrm{AO} 7[\mathrm{M}+\mathrm{Na}]^{+}$, which was identical to the result of $[\mathrm{M}-\mathrm{Na}]^{-}$at $\mathrm{m} / \mathrm{z} 327$. After $30 \mathrm{~min}$ of incubation, new peaks at $\mathrm{m} / \mathrm{z} 165,215$ and 257 were observed. The ions of $\mathrm{m} / \mathrm{z} 215$ and 165 can be attributed to the oxidized compounds of 1,2-naphthoquinone. Besides, $\mathrm{m} / \mathrm{z} 257$ can be a product of radical attack and further oxidation of the ion $\mathrm{m} / \mathrm{z} 261,165$. It should be noted that the observation of ions after a long reaction time does not mean their later appearing as the detection of ions by ESI-MS is related not only to the concentration but the degree of ionization as well.

Therefore, a reaction sequence for $\mathrm{AO} 7$ degradation in the $\mathrm{HSO}_{3}^{-} / \mathrm{PS} / \mathrm{Vis}$ system was proposed based on the analyses of the ESI-MS data. It is shown in Figure 5. Firstly, an initial successive radical attacked the $\mathrm{N}$ atom of the dye, which decomposed to p-PSA and oxidized products of 1,2-naphthoquinone. Then, subsequent oxidation of these products and loss of the $-\mathrm{SO}_{3}^{-}$group occurred. Finally, acyclic carboxylic acids formed from the central ring-opening, and then they were further oxidized to simple carboxylic acids. Obviously, this proposed partial pathway only depended on ESI-

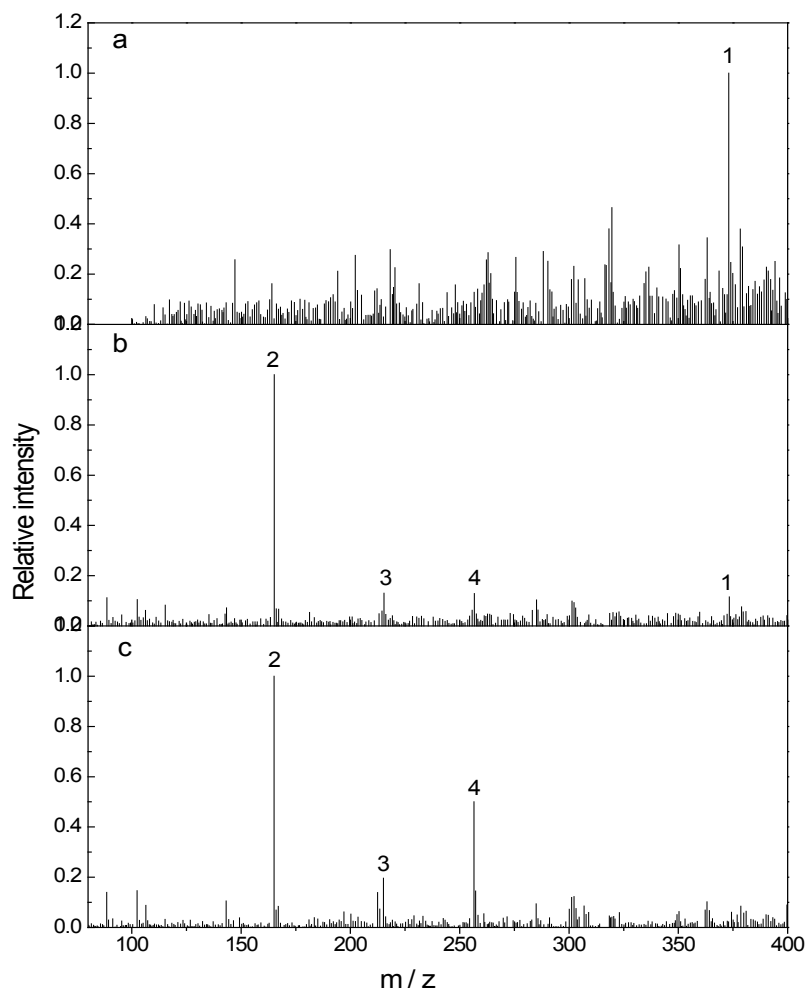

Fig. 4. $\mathrm{ESI}(+)$ mass spectra of $\mathrm{AO}$ 7 solution during degradation in the $\mathrm{Vis} / \mathrm{HSO}_{3}{ }^{-} / \mathrm{PS}$ system at different time intervals $(\mathrm{min})$ :

(a) 0, (b) 30, (c) 60 

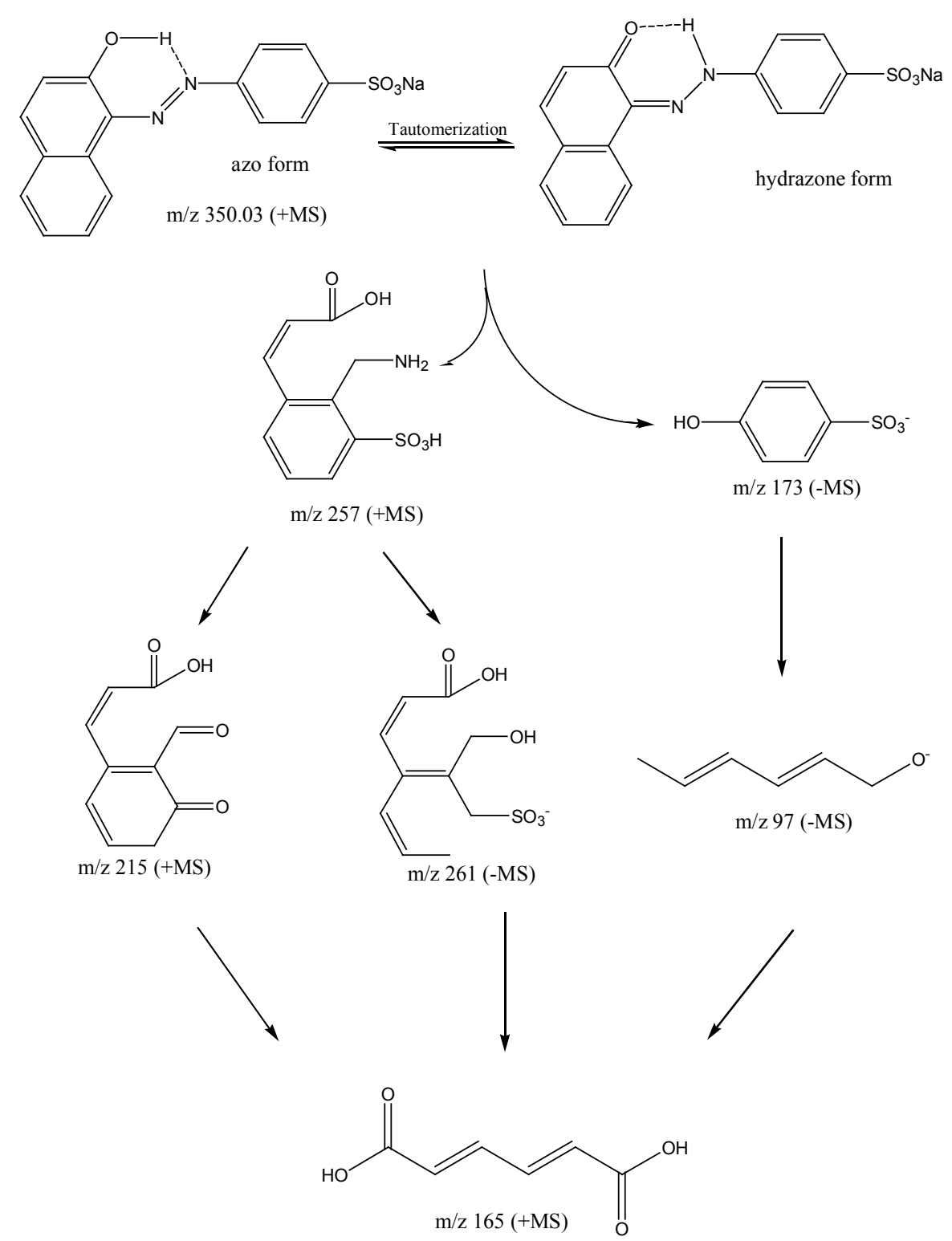

Fig. 5. Scheme of a proposed pathway for $\mathrm{AO} 7$ degradation in the $\mathrm{Vis} / \mathrm{HSO}_{3}-/ \mathrm{PS}$ system

MS and relevant literature, and it still needs to be investigated systematically.

Arrangement of effective quality control over the discharge of process water and products of its treatment at local wastewater treatment facilities of industrial plants prevents hazardous biological substances from entering the hydrosphere. Such quality control is especially important if treated wastewater and wastewater processing products are re-used [10].

Peak values: (1) 373, (2) 165, (3) 215, (4) 257.

\section{Conclusion}

The mechanism of $\mathrm{AO} 7$ degradation in the $\mathrm{HSO}_{3}^{-} / \mathrm{PS} / \mathrm{Vis}$ treatment process was investigated, with a particular focus on $\mathrm{AO} 7$ degradation pathways. The presence of EtOH and TBA hindered AO7degradation, indicating that $\cdot \mathrm{OH}$ radicals are the major radical species participating in the $\mathrm{AO} 7$ decolorization process, where $\mathrm{SO}_{4} \cdot{ }^{-}$is also involved. Based on the ESI-MS analysis of the degradation intermediates, the pathway of $\mathrm{AO} 7$ degradation in the $\mathrm{HSO}_{3}^{-} / \mathrm{PS} / \mathrm{Vis}$ system was proposed. The $\mathrm{C}-\mathrm{N}$ bonds of $\mathrm{AO} 7$ were attacked by the radicals, and 
smaller compounds, such as p-PSA and simple carboxylic acids, +formed.

\section{Acknowledgements}

The authors express their gratitude to the Russian Ministry of Education and Science (grant No. 01.03.005), Russian Foundation for Basic Research (grant No. 04-05-78035), Chinese High Technology Project Fund (863, grant No. 2009AA063904) for financial support.

\section{References}

1. Azam A., Hamid A. (2006). Effects of gap size and UV dosage on decolorization of C.I. Acid Orange 7 by UV/ $\mathrm{H}_{2} \mathrm{O}_{2}$ process. Journal of Hazardous Materials, Vol. 133, Issues 1-3, pp. 167-171. DOI: 10.1016/j.jhazmat.2005.10.005.

2. Chen X., Chen J., Qiao X., Wang D., Cai X. (2008). Performance of nano- $\mathrm{Co}_{3} \mathrm{O}_{4} /$ peroxymonosulfate system: Kinetics and mechanism study using Acid Orange 7 as a model compound. Applied Catalysis B: Environmental, Vol. 80, Issues 1-2, pp. 116-121. DOI: 10.1016/j.apcatb.2007.11.009.

3. Chen X., Qiao X., Wang D., Lin J., Chen J. (2007). Kinetics of oxidative decolorization and mineralization of Acid Orange 7 by dark and photoassisted Co2+-catalyzed peroxymonosulfate system. Chemosphere, Vol. 67, Issue 4, pp. 802-808. DOI: 10.1016/j.chemosphere.2006.10.032.

4. Coughlin M. F., Kinkle B. K., Bishop P. L. (2002). Degradation of acid orange 7 in an aerobic biofilm. Chemosphere, Vol. 46, Issue 1, pp. 11-19. DOI: 10.1016/S00456535(01)00096-0.

5. KláSek A., BačáKová M., Kaszonyiová A., Pavelka F. (1985). Bisulfite-persulfate-initiated grafting of methyl methacrylate onto gelatin. Journal of Applied Polymer Science, Vol. 30, Issue 2, pp. 515-529. DOI: 10.1002/ app.1985.070300206.

6. Liang C., Su H.-W. (2009). Identification of sulfate and hydroxyl radicals in thermally activated persulfate. Industrial \& Engineering Chemistry Research, Vol. 48, Issue 11, pp. 55585562. DOI: $10.1021 / \mathrm{ie} 9002848$.

7. López C., Valade A.G., Combourieu B., Mielgo I., Bouchon B., Lema J.M. (2004). Mechanism of enzymatic degradation of the azo dye Orange II determined by ex situ $1 \mathrm{H}$ nuclear magnetic resonance and electrospray ionization-ion trap mass spectrometry. Analytical Biochemistry, Vol. 335, Issue 1, pp. 135-149. DOI: 10.1016/j.ab.2004.08.037.

8. Méndez-Paz D., Omil F., Lema J.M. (2005). Anaerobic treatment of azo dye Acid Orange 7 under batch conditions. Enzyme and Microbial Technology, Vol. 36, Issues 2-3, pp. 264-272. DOI: 10.1016/j.enzmictec.2004.08.039.

9. Misra B.N., Dogra R., Mehta I.K., Gill K.D. (2003). Grafting onto wool. XI. Graft copolymerization of poly(vinyl acetate) and poly(methyl acrylate) onto reduced wool in presence of potassium persulfate-ferrous ammonium sulfate (KPS-FAS) system as redox initiator. Journal of Applied Polymer Science, Vol. 26, Issue 11, pp. 3789-3796. DOI: 10.1002/app.1981.070261125.

10. Nevsky A.V., Meshalkin V.P., Sharnin V.A. (2004). Analysis and synthesis of water resource-saving chemicalengineering systems. Moscow: Nauka, 212 p.
11. Özcan A., Oturan M. A., Oturan N., Şahin Y. (2009). Removal of Acid Orange 7 from water by electrochemically generated Fenton's reagent. Journal of Hazardous Materials, Vol. 163, Issues 2-3, pp. 1213-1220. DOI: 10.1016/j. jhazmat.2008.07.088.

12. Peebles Jr. L.H. (1973). A kinetic model of persulfatebisulfite-initiated acrylonitrile polymerization. Journal of Applied Polymer Science, Vol. 17, Issue 1, pp. 113-128. DOI: 10.1002/app.1973.070170109.

13. Shi W., Cheng Q., Zhang P., Ding Y., Dong H., Duan L., Li X., Xu A. (2014). Catalytic decolorization of methyl orange by the rectorite-sulfite system. Catalysis Communications, Vol. 56, pp. 32-35. DOI: 10.1016/j.catcom.2014.06.029.

14. Tsuda Y. (1961). A tracer study of the persulfatebisulfite-catalyzed polymerization of acrylonitrile. Journal of Applied Polymer Science, Vol. 5, Issue 13, pp. 104-107. DOI: 10.1002/app.1961.070051316.

15. Wu J., Zhang H., Qiu J. (2012). Degradation of Acid Orange 7 in aqueous solution by a novel electro/ $\mathrm{Fe} 2+$ /peroxydisulfate process. Journal of Hazardous Materials, Vol. 215-216, pp. 138-145. DOI: 10.1016/j. jhazmat.2012.02.047.

16. Yang S., Wang P., Yang X., Shan L., Zhang W., Shao X., Niu R. (2010). Degradation efficiencies of azo dye Acid Orange 7 by the interaction of heat, UV and anions with common oxidants: Persulfate, peroxymonosulfate and hydrogen peroxide. Journal of Hazardous Materials, Vol. 179, Issue 1-3, pp. 552-558. DOI: 10.1016/j.jhazmat.2010.03.039.

17. Yang S., Yang X., Shao X., Niu R., Wang L. (2011). Activated carbon catalyzed persulfate oxidation of Azo dye acid orange 7 at ambient temperature. Journal of Hazardous Materials, Vol. 186, Issue 1, pp. 659-666. DOI: 10.1016/j. jhazmat.2010.11.057.

18. Zhang S.-J., Yu H.-Q., Li Q.-R. (2005). Radiolytic degradation of Acid Orange 7: A mechanistic study. Chemosphere, Vol. 61, Issue 7, pp. 1003-1011. DOI: 10.1016/j. chemosphere.2005.03.008.

19. Zhang X., Wang Y., Li G., Qu J. (2006). Oxidative decomposition of azo dye C.I. Acid Orange 7 (AO7) under microwave electrodeless lamp irradiation in the presence of $\mathrm{H}_{2} \mathrm{O}_{2}$. Journal of Hazardous Materials, Vol. 134, Issues 1-3, pp. 183-189. DOI: 10.1016/j.jhazmat.2005.10.046.

\section{Authors}

\section{Zhong Heng}

General Chemical Engineering Department, Ivanovo State University of Chemistry and Technology, Ivanovo, Russia

School of Environmental Engineering, Wuhan Textile University, Wuhan, China

E-mail: zhong359324658@163.com

\section{Sun Lei}

General Chemical Engineering Department, Ivanovo State University of Chemistry and Technology, Ivanovo, Russia

School of Environmental Engineering, Wuhan Textile University, Wuhan, China

E-mail: stylelife@live.com 
Fang Jia

School of Chemistry and Chemical Engineering, Wuhan Textile University, Wuhan, China

E-mail:954233220@qq.com

\section{Zhao Hui}

General Chemical Engineering Department, Ivanovo State University of Chemistry and Technology, Ivanovo, Russia

School of Environmental Engineering, Wuhan Textile University, Wuhan, China

E-mail: 771361793@qq.com

\section{Xu Aihua}

School of Environmental Engineering, Wuhan Textile University, Wuhan, China

E-mail: xahspinel@sina.com

Xia Dongsheng, Doctor of Science, Professor

School of Environmental Engineering, Wuhan Textile University, Wuhan, China

E-mail: xds01@163.com

Nevsky Alexander Vladimirovich, Doctor of Science, Professor

General Chemical Engineering Department, Ivanovo State University of Chemistry and Technology, Ivanovo, Russia

School of Environmental Engineering, Wuhan Textile University, Wuhan, China

E-mail:nevsky@isuct.ru

\section{Авторы}

Чжун Хэн

Ивановский государственный химико-технологический университет, г. Иваново, Россия

Уханьский текстильный университет, г. Ухань, Китай

E-mail: zhong359324658@163.com

\section{Сунь Лэй}

Ивановский государственный химико-технологический университет, г. Иваново, Россия

Уханьский текстильный университет, г. Ухань, Китай

E-mail: stylelife@live.com

\section{Фан Цзя}

Уханьский текстильный университет, г. Ухань, Китай E-mail:954233220@qq.com

\section{Чжао Хуэй}

Ивановский государственный химико-технологический университет, г. Иваново, Россия

Уханьский текстильный университет, г. Ухань, Китай

E-mail: 771361793@qq.com

\section{Сюй Айхуа}

Уханьский текстильный университет, г. Ухань, Китай

E-mail: xahspinel@sina.com

Ся Донченг, доктор наук, профессор

Уханьский текстильный университет, Китай

E-mail: xds01@163.com

Невский Александр Владимирович, д-р техн. наук, профессор

Ивановский государственный химико-технологический университет, г. Иваново, Россия

Уханьский текстильный университет, г. Ухань, Китай

E-mail: nevsky@isuct.ru 
Подписано к печати 18.09.2019. Формат $60 \times 901 \%$. Бумага офсетная. Усл. печ. л. 10,5. Тираж 1000 экз. Заказ 114. «С» 53. Отпечатано на МФУ. 198095, Санкт-Петербург, ул. Розенштейна, д. 32, лит. А 